DOI: $10.1515 /$ hssr -2015-0022

\title{
The Shivers of Knowledge
}

Félix Schoeller*

École des Hautes Études en Sciences Sociales. C.R.A.L., Paris

\begin{abstract}
Aesthetic chills occur in artistic, scientific and religious context. We introduce a theoretical framework relating them to humans' vital need for cognition. We discuss the implications of such a framework and the plausibility of our hypothesis. Numerous references to chills are introduced (quotes from, inter alios, artists, physicists and mathematicians).
\end{abstract}

Keywords

Aesthetic chills, Knowledge, Curiosity, Pleasure

\section{Introduction}

In an introduction to Moritz Schlick's last years of philosophical thought, Friedrich Waismann mentions a note found among the papers of the late founder of the Vienna Circle. In this note, the philosopher recalls his younger days of schooling at the Luisenstädtisches Realgymnasium in Berlin by the end of the 19th century. Comenting on Schlick's reflections, Waismann notes:

It was there that his deeper interests were first aroused by one of his teachers, who opened to him the intellectual world of mathematics and physics. How deep must have been the impression gained from these conversations, he has recorded in a note among his papers, where he speaks of the 'shivers of knowledge' which coursed down his spine. (Waismann in Schlick, 1979: XIII)

\footnotetext{
* École des Hautes Études en Sciences Sociales. C.R.A.L., Paris, France, 96, Boulevard Raspail, 75006, Paris, France, felix.schoeller@ehess.fr
} 
Nearly thirty years later, the same Moritz Schlick wrote that "we find within ourselves a thirst for knowledge, a desire to explain, a craving for answers to endless questions ; and everyone who thinks has some moments in his life when he asks himself : Can this thirst be quenched at all ? Can this desire for knowledge be satisfied; and if so, how far can it be satisfied ?" (Schlick, 1979b). In what follows we shall attempt to provide reasonable views, useful distinctions, substantial arguments and empirical evidence in order to address to the best of our ability this fundamental question.

\section{The Instinct of Knowledge}

The world is infinitely complex, various, mutable, a perpetual flux of states and relations of things, but we rarely find it incoherent or absurd and every new object encountered always seems to fit a pre-existing category. To some extent, it is as though there existed in humans a natural tendency to maximize the adequacy between the world and the mental representations formed on its basis ; in Festinger's words "the reality which impinges on a person will exert pressures in the direction of bringing the appropriate cognitive elements into correspondence with that reality" (1957: 11). In fact, this process is so effective that it is not rare to witness some confuse one for the others so that they no longer distinguish between them. To quote Daniel Berlyne, the pre-eminent authority on curiosity in the field of psychology:

Any new experience, even if it does not seem to be a combination of familiar experiences, must have some definite degree of resemblance to experiences that have occurred before. [...] The new stimulus can be related to well-known stimuli by expressing the differences between it and them quantitatively. [...] The nervous system relates any novel incoming stimulus to stimulus categories that it already recognizes; a new stimulus will evoke responses corresponding to familiar stimuli by generalization, and it will evoke them with strengths corresponding to its resemblance to the stimuli with which the responses were originally associated. (Berlyne, 1960: 19, our emphasis)

Even though every single state of affairs is hardly comparable to any other, and, depending on the light, the perspective or the setting, the same object never appears twice similar to itself, humans restlessly 
observe the present through the prism of the past and in the eyes of the future. From this, one may reasonably posit that humans' reduce their uncertainty about the unfolding of external events by habit. They do so naturally, in the sense that it is impossible for one to stop the process permanently. Indeed, this restrictive influence is characteristic of instincts; but are we really as inclined to think in a given situation as we are to laugh when we are tickled?

According to William James, instincts describe the appropriate and natural thing to do in a given context. They provide us with the faculty of acting in such a way as to produce certain ends, without foresight of the ends and without previous education in the performance (James, 1890, Ch. 24). As a result of this, they are most evident during childhood and are usually intimately known by all, so that they are rarely socially questioned. James then extends his discussion to the biological level and concludes that "with the presence of a certain organ goes almost always a native aptitude for its use". One may reasonably ask: what is the native aptitude, intimately known and explicitly unquestioned by all, for the usage of the human brain? What is the origin of the natural complexity of its organelles as opposed to that of toads and whales?

Since Aristotle (though not always in the same manner nor for the same reasons), it has been quite common for Western scholars interested in such matters to impose on our minds the function of thinking, that is, the ability to generalize on the basis of certain redundancies distinguished in modification of our sense organs. Lovejoy, in his Reflections on the history of ideas remarked that "whatever other definitions of man be true or false, it is generally admitted that he is distinguished among the creatures by the habit of entertaining general ideas" (Lovejoy, 1940). Introspection is quite revealing in this regard. How impossible is it for us to see a man behind his uniform, to hear phonetics and not semantics, to view shapes and not letters, to look at a face and not at a friend!

But how is it that we come to acquire knowledge ${ }^{1}$ in the first place? One of the fundamental biological prerequisites for survival is the exploration and understanding of environmental conditions and, in very much the same manner as eating implies a vital need for food, thinking implies a vital need for information. In fact, there is strong evidence for 
an antagonistic relationship between exploratory and eating responses (Chance \& Mead, 1955). Studies in ethology suggest that higher mammals and birds have a distinct appetence for novelty (EiblEibesfeldt, 1987, 1989). Young mammals are particularly curious, intentionally placing themselves in new situations and exploring new objects (Berlyne, 1957). Humans are born with phylogenetically based a priori knowledge (see e.g., Gopnik \& Meltzoff, 1997; Carey \& Spelke, 1994; see also Gopnik, 1998), pre-given categories which also include a series of learning dispositions and an exploratory drive known as curiosity (Eibl-Eibesfeldt, 1989; Berlyne, 1960). This drive develops in learning animals in the service of knowledge acquisition. It is a juvenile characteristic in animals but it sustains itself in human beings into advanced age (e.g., Lorenz, 1970).

Anthropologists such as Laughlin and d'Aquili have also posited the existence of a cognitive imperative. According to these authors, "the cognitive imperative is the assimilating operator whose function is to bring novel environmental stimuli into ordered concert with other events and entities modeled in the organism's cognized environment" (Laughlin and d'Aquili, 1972: 12). The satisfaction of the drive leads to pleasure and eventual system enhancement, its frustration leads to anxiety and eventual system breakdown. These authors were the first that we know of to link (though not intentionally) the instinct of knowledge to chills and shivers (1979: 177).

In more philosophical terms, the instinct of knowledge could be defined as the natural reflex that humans have to track and anticipate patterns in experience, generalize on the basis of particulars while seeking for coherence and logical simplicity. It is intimately connected to curiosity, since they are both necessary conditions for any type of knowledge-acquisition. In philosophy, the idea that man is best defined by a desire for knowledge was first advocated by Aristotle (e.g., De Anima. Ii. 3; Metaphysics. i.1). Edmund Burke started his Inquiries by stating that "the first and the simplest emotion which we discover in the human mind is curiosity" and the same intuition motivates Hume's Treatise (1738, in particular Book 2, Sec. 10). A piece of mechanism cannot work perpetually without being fed with power in some form and, in the fifth paragraph of his Enquiry Concerning Human Understanding, 
Hume uses precisely this very controversial notion of instinct to describe the motive power of the machinery of the mind.

As nature has taught us the use of our limbs, without giving us the knowledge of the muscles and nerves, by which they are actuated; so has she implanted in us an instinct, which carries forward the thought in a correspondent course to that which she has established among external objects; though we are ignorant of those powers and forces, on which this regular course and succession of objects totally depends. (Hume, Enquiry, V)

Charles Sanders Peirce (1997/1903) also posited the presence in humans of an "instinct, resembling the instincts of the animals in its so far surpassing the general powers of our reason and for its directing us as if we were in possession of facts that are entirely beyond the reach of our senses" (par. 173). More recently, Hermann Broch (1951) mentions quite extensively what he refers to as a Promethean thrust toward knowledge; that is, the human faculty and duty that we have to cultivate the field of our understanding.

This natural drive towards generalization is as vital to our species as food and sex, since only through such a reductive process can we confine into adequate categories the incredible complexity of the world and overcome the weaknesses inherent to our biological constitution. It has consequences on perceptual, emotional and cognitive processes. Mathematically, it may be formalized as a maximization of a similarity measure between mental models and the world (Perlovsky, 2000). The mind is thus viewed as a multi-level, hetero-hierarchical system. Let us briefly review some of the most relevant implications such a computational framework involves before focusing on aesthetic chills.

\section{The mind as a hetero-hierarchical system}

Whether biological or artificial, any information processing system has limited capacity. Therefore, the accumulation of knowledge obeys laws of restriction and the inner working of the mind are best described in terms of economy. The black box is a box, there is a limited amount of things you can put in a box and only one way to assemble as many of them as you can. Given the limited-capacity of the human brain, two 
HSS, vol. IV, no. 3 (2015): 26-41

fundamental principles may be derived: (i) cognitive economy requires adequate knowledge significant to the objectives of the system (Grossberg and Levine, 1987) and (ii) such adequacy implies polarization, since the very process of thinking (the act of determining the adequacy of a given piece of knowledge) involves the evaluation of contradictory options (Lupasco, 1947, Festinger, 1959, 1962). Mach (1959) refers to them as (i) the principle of broadest possible generalization and (ii) the principle of sufficient differentiation. In order to assess whether this given table is black, I need to be able to consider what it would mean for this table not to be black. I also need to know that this particular table falls under the general category of 'tables' and that it might be similar to other objects which I categorize as being 'black'. As a consequence, knowledge matrices are usually presented as vertically hierarchical and horizontally categorical (figure 1). For the instinct of knowledge to be satisfied, one therefore needs to find evidence that it is functional on both levels.

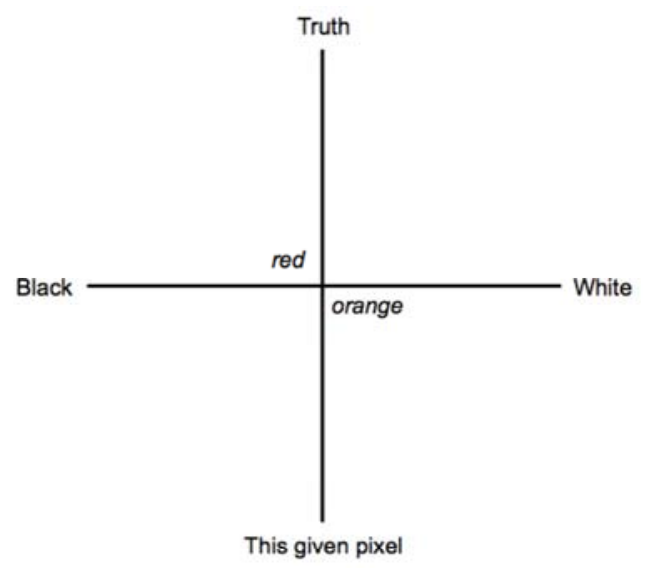

Theoretical architecture of the human mind.

The knowledge matrix is vertically hierarchical and horizontally categorical. Truth is a much more general piece of knowledge than information available regarding this given pixel and black is the contrast opposite of white. Under uncertainty, the greater the distance on the abscissa, the greater the magnitude of dissonance and the more necessary 
its reduction (usually by creation of a new layer in the hierarchy). Compare the sensation of seeing a white table and being told by a large group of people that it is black to that of seeing an orange table and being told by the same group that it is red (if the visible spectrum is your field of specialty, you may very well replace these categories by political categories ranging from liberal to conservative).

Cognitive resources being limited, the acquisition of knowledge implies its structuration in adequate categories. Indeed, these categories have different levels of abstraction. Knowledge about the world is more or less sophisticated, more or less meaningful, more or less general, more or less deep. Hierarchies are fundamental to the cognitive system for two main reasons : (i) they provide stable intermediate forms which are necessary for simple systems to evolve rapidly in more complex forms (Simon, 1962) and (ii) they permit to overcome combinatorial complexity (Albus \& Meystel, 2001). The mind can thus be modeled as a heterohierarchical system (e.g., Perlovsky, 2006a, 2006b). At the top of the hierarchy one would find the most sophisticated, most meaningful, most abstract, most general concepts (such as God and truth); and at the bottom, the less sophisticated, less meaningful, less abstract, less general representations (such as the peel of this banana or the stain on that table). The genius of great writers resides in their ability to slide one into the other, to reveal God in the stain and truth in the peel. Information about stains and bananas is usually treated automatically in a bottom-up fashion, whereas the treatment of highly general concepts demands much more effort and cognitive resources. It might be conjectured that processing fluency, characteristic of the appreciation of great art, and the pleasure that is associated with it, could be due to this sensible interlacing of depth and triviality. This guesswork has played an important role in the determination of the stimulus we used for our own experiments (Schoeller, 2015). We have chosen a film that is both general and particular (it can be described at both levels), meaningful and transparent (it is easily understandable but difficult to verbalize), abstract and concrete (it is a dance sequence but, according to our subjects, it expresses much more than mere bodily movements) and, finally, it presents both admirable simplicity (in terms of properties) and complex sophistication (in terms of technique). But we are not interested here in 
what causes aesthetic chills per se, rather in their relation to humans' curiosity and instinct of knowledge.

The strive for information and its biological limitations increases possibilities for conflictual antinomies, since novel information always holds a chance to contradict pre-existing knowledge about the world. In fact, it is well known for rigorous scholars that the more you learn on a given subject, the more you research a specific array of knowledge, the more you extend this array, the more you realize how extendable it actually is and how small of a portion your former understanding of the problem actually was. As a consequence of this, there exists a theoretical relationship between the magnitude of what is usually referred to in psychology as dissonance (in logical terms, inconsistency) and the inclination to seek out new information (Festinger, 1957: 130). The more you extend your knowledge on a given subject, the more likely you are to encounter information which will contradict it and thus "the brain of higher organisms tends to strive for a balance between novelty and redundancy in the environment" (Berlyne, 1960). Our hypothesis here is that when such a balance is to be found in the environment, when external events validate internal models at their highest levels, subjects should be rewarded with intense pleasure (i.e., aesthetic chills).

In sum, the instinct of knowledge has strict biological limitations, these limitations imply that knowledge must be structured in a coherent and economical manner. A simple and useful kind of structure would be one where knowledge is vertically hierarchical and horizontally polarized. The accumulation of knowledge implies the creation of higher cognitive categories and greater horizontal discrepancies. Satisfaction of the instinct should have consequences on both axis.

\section{Aesthetic chills}

Chills are a muscular phenomenon, they are best described as the sensation of coldness created by a rhythmic oscillating tremor of skeletal muscles. Often associated with goose bumps (i.e., transient contractions of arrector pili muscles) though there is some disagreement on the nature of the construct, chills are commonly referred to in the literature as cutis anserina, feeling of cold in the back, shivers down the spine (etc.). To this date, there exists no systematic explanation as to why this biological 
HSS, vol. IV, no. 3 (2015): 26-41

phenomenon should occur in an aesthetic context. In his Lecture on literature, Nabokov expressed the view that art is about creating a tingle between the shoulder blades.

It seems to me that a good formula to test the quality of a novel is, in the long run, a merging of the precision of poetry and the intuition of science. In order to bask in that magic a wise reader reads the book of genius not with his heart, not so much with his brain, but with his spine. It is there that occurs the telltale tingle even though we must keep a little aloof, a little detached when reading. (Nabokov, 1981: 64)

In very much the same manner Bernard Berenson, an authority on Renaissance art, describes the aesthetic experience as such: "what I can say is that in my own case it is accompanied by an ideated tingling on and in my own skin corresponding to eye movement, both retinal and muscular, but that the feeling as a whole is one of aesthetic identification, as if there were nothing in me that was not living the life of the contour" (Berenson, 1948: 71). But art is not the sole source of aesthetic chills. See, rather, this quote from James W. Cronin ${ }^{2}$ reflecting on his research in particle physics.

So these gentlemen, Gell-Mann and Pais, predicted that in addition to the short-lived $\mathrm{K}$ mesons, there should be long-lived $\mathrm{K}$ mesons. They did it beautifully, elegantly and simply. I think theirs is a paper one should read sometime just for its pure beauty of reasoning. It was published in the Physical Review in 1955. A very lovely thing! You get shivers up and down your spine, especially when you find you understand it. (Cronin, 1982: 40, our emphasis)

The mathematician G.N. Watson, who spent several years of his life proving many of Ramanujan's astonishing identities, hold similar statements about some of them (refer to e.g., Chandrasekhar, 1987). Similarly, Lamé once expressed (see e.g., O'Connor and Robertson, 2015) that in reading Hermite's memoirs on the theory of modular functions, on a la chair de poule ("one has goose bumps"). The practice of physics and mathematics seems to be a strong elicitor for aesthetic chills, but their presence may also be encountered in religious contexts. 
Evidence for this is found in the work of Armstrong in humanistic anthropology (1971), in that of D'aquili and Laughlin (1979) or of Deborah Neff on rituals in rural Kurala (1987). When presenting his marvelous finds on the religion and ideology of the Lepenski Vir culture, Srejovic talked about a frisson sacré (Srejovic, 1972) which indeed is not without reminding the last part of Schiller's Veiled image at Saïs ${ }^{3}$ or the last section of Hölderlin's Hyperion ${ }^{4}$. More recently, evidence for the presence of aesthetic chills in religious context is found in the work of Diana Espírito Santo on Cuban Espiritismo (2015) and that of Joel Inbody on Pentecostalism (2015).

As a result of the research conducted in the last thirty years, quite a lot is thought to be known about phenomena such as chills, shivers and gooseflesh (e.g., Maruskin, Trash and Elliot, 2007; Grewe et al., 2010; Harisson and Loui, 2014). Measurable physiological correlates have been proposed (e.g., Grewe et al., 2007), brain activation patterns identified (e.g., Blood and Zatorre, 2001; Craig, 2005) and evolutionary accounts suggested (e.g., Panksepp and Bernazky, 2002). But, as noted by the late John Archibald Wheeler (1983), measurement does not make sense until one has a rational theory of what it is one is measuring. The major issue when trying to subsume the occurrence of such phenomena under general laws still remains the variety of causal factors involved. The particular case of pilomotor reflexes is quite revealing. Piloerection has been shown by studies conducted in cognitive musicology to be triggered by both unpleasant (e.g., Halpern, et al., 1986) or pleasant sound frequencies (e.g., Grewe et al., 2005). Goldstein (1980) found thrills to be more often elicited by happy music than by sad music while Panksepp (1995) studied the same phenomenon and found it more often elicited by sad music than by happy music. Furthermore, these reflexes, as they are reflection of sympathetic nerve discharge, also frequently occur in the absence of any emotional processes - e.g., in the case of immediate homeostatic responses involved in body thermoregulation.

In psychology of emotion and music cognition, the study of aesthetic chills has been described under the terms frisson (Sloboda, 1991 ; Huron, 2006), chills (e.g., Grewe et al., 2009, Guhn et al., 2007), strong or transcendant experiences (Baltes, Avram, Miclea and Miu, 2011; Gabrielsson, 2011; Harisson \& Loui, 2014), thrills (e.g., Huron and 
Margulis, 2011 ; Goldstein, 1980, Konecni et al., 2007), awe (Keltner \& Haidt, 2003; Lazarus, 1991, Pearsall, 2007), aesthetic chills (McCrae, 2007), admiration (Algoe \& Haidt, 2009) or skin orgasm (Panksepp, 1995). Our working hypothesis is that these biological events correspond to a satisfaction of the instinct of knowledge (Schoeller, 2015).

We tested this working hypothesis in four explorative studies conducted in a laboratory at the University of Copenhagen. At the psychophysiological level, aesthetic chills were positively correlated with curiosity and exposition to an incoherent prime seems to be a strong inhibitor. At the narratological level, we analyzed the properties of chilleliciting scenes and discussed them in the light of redundancies noticed in the phenomenological descriptions provided by our subjects. We arrived to the conclusion that chill-eliciting scenes facilitate the acceptance of fundamental cognitive conflicts and help us reduce cognitive dissonances of maximum amplitude. That is, contradiction involving pairs of cognitions of equal total resistance to change where the less resistant element may not be altered nor the amount of dissonance reduced. Following Festinger's intuition (see his discussion of the Ifaluk belief system in 1957: 22), we proposed that chill-eliciting scenes might provide subjects with new cognitive elements maintaining the total dissonance of the system at a rather low level. If these results were to be corroborated by more empirical data, these findings could lead to major therapeutic outcomes and we strongly recommend researchers to replicate our protocol in a different socio-cultural context.

\section{Conclusion}

Learning and improving our knowledge about the world is analogous to the activity of "sailors who have to rebuild their ship on the open sea" (Schlick, 1932: 33-44). The task may appear vain to many, and in fact the greatest minds have given up on the sail of truth before, albeit a raft must see the light of day. Healthy subjects think, not because they can but because they must. It is impossible for them not to do so. The mind functions in such a way that it restlessly proceeds to remove uncertainty, supplement and complete half-observed facts. Humans are naturally driven to organize unexplained external stimuli into some coherent cognitive matrix. We presented a theoretical framework in which the 
HSS, vol. IV, no. 3 (2015): 26-41

elements of such a matrix are organized hierarchically and differentiated between polar opposites. The only way in which this activity can come to its term is for the instinct of knowledge to be satisfied and for the cognitive system to prove both perennial and functional. Recent results suggest that aesthetic emotions might correspond to such a psychobiological event.

\section{References}

Albus, J. S. and Meystel, A. (2001). Engineering of Mind: an Introduction to the Science of Intelligent Systems. Wiley: New York.

Algoe, S. B. and Haidt, J. (2009). "Witnessing excellence in action: the 'otherpraising' emotions of elevation, gratitude, and admiration". J Posit Psychol, 4(2):105-127.

Armstrong, R. P. (1971). The Affecting Presence: An Essay in Humanistic Anthropology. University of Illinois Press, Urbana.

Baltes, F. R., Avram, J., Miclea, M., and Miu, A. C. (2011). "Emotions induced by operatic music: psychophysiological effects of music, plot, and acting: a scientist's tribute to Maria Callas". Brain Cogn, 76(1): 146-57.

Berenson, B. (1948). Aesthetics and History in the Visual Arts. Pantheon.

Berlyne, D. E. (1954a). "An experimental study of human curiosity". Br J Psychol, 45(4): 256-65.

Berlyne, D. E. (1954b). "A theory of human curiosity". Br J Psychol, 45(3) :18091.

Berlyne, D. E. (1955). "The arousal and satiation of perceptual curiosity in the rat". J Comp Physiol Psychol, 48(4): 238-46.

Berlyne, D. E. (1960). Conflict, Arousal, and Curiosity. McGraw-Hill Series in Psychology. New York: McGraw-Hill.

Berlyne, D. E. (1962). "Uncertainty and epistemic curiosity". Br J Psychol, 53: 27-34.

Berlyne, D. E. (1971). Aesthetics and Psychobiology. The Century Psychology Series. New York: Appleton-Century-Crofts.

Berlyne, D. E. and Slater, J. (1957). "Perceptual curiosity exploratory behavior, and mazelearning". J Comp Physiol Psychol, 50(3):228-32.

Blood, A. J. and Zatorre, R. J. (2001). "Intensely pleasurable responses to music correlate with activity in brain regions implicated in reward and emotion”. Proc Natl Acad Sci U S A, 98(20): 11818-23.

Carey, S. and Spelke, E. S. (1996). "Science and core knowledge". Philosophy of Science, 63: 515-533. 
HSS, vol. IV, no. 3 (2015): 26-41

Chance, M. R. A. and Mead, A. P. (1955). "Competition between feeding and investigation in the rat". Behaviour, 8(2):174-182.

Chandrasekhar, S., Truth and Beauty (1987). Illinois : University of Chicago Press.

Craig, D. (2005). "An exploratory study of physiological changes during "chills" induced bymusic". Musicae Scientiae, IX(2) :273-287.

Espírito Santo, D. (2015), "Liquid sight, thing-like words, and the precipitation of knowledge substances in Cuban espiritismo". Journal of the Royal Anthropological Institute, 21: 579-596. Doi: 10.1111/1467-9655.12252

Festinger, L. (1957). A Theory of Cognitive Dissonance. Row, Peterson, Evanston, Ill.

Festinger, L. (1962). "Cognitive dissonance”. Sci Am, 207: 93-102.

Festinger, L. and Carlsmith, J. M. (1959). "Cognitive consequences of forced compliance”. J Abnorm Psychol, 58(2): 203-10.

Festinger, L. and Hutte, H. A. (1954). "An experimental investigation of the effect of unstable interpersonal relations in a group". J Abnorm Psychol, 49 (1, Part 1): 513-22.

Goldstein, A. (1980). "Thrills in response to music and other stimuli". Physiological Psychology, 8: 126-129.

Gopnik, A. (1998). "Explanation as orgasm". Minds and Machines, 8(101-118).

Grewe, O., Kopiez, R., and Altenmüller, E. (2009). "Chills as an indicator of individual emotional peaks”. Ann N Y Acad Sci, 1169: 351-4.

Grewe, O., Nagel, F., Kopiez, R., and Altenmüller, E. (2005). "How does music arouse "chills"? investigating strong emotions, combining psychological, physiological, and psychoacoustical methods". Ann N Y Acad Sci, 1060: 446-9.

Gopnik, A. and Meltzoff, A. N. (1997). Words, Thoughts, and Theories. Cambridge, Mass : MIT Press.

Grossberg, S. and Levine, D. S. (1987). "Neural dynamics of attentionally modulated pavlovian conditioning: blocking, interstimulus interval, and secondary reinforcemen". Appl Opt, 26(23): 5015-30.

Guhn, M., Hamm, A., and Zentner, M. (2007). "Physiological and musicoacoustic correlates of the chill response". Music Perception, 24(5): 473-483.

Harrison, L. and Loui, P. (2014). "Thrills, chills, frissons, and skin orgasms: toward an integrative model of transcendent psychophysiological experiences in music". Front Psychol, 5: 790.

Huron, D. B. (2006). Sweet Anticipation: Music and the Psychology of Expectation. Cambridge, Mass: MIT Press. 
HSS, vol. IV, no. 3 (2015): 26-41

Inbody, J. (2015). "Sensing God: Bodily Manifestations and Their Interpretation in Pentecostal Rituals and Everyday Life", Sociology of Religion: srv032v1-srv032.

James, W. (1890). The Principles of Psychology. New York: H. Holt and company.

Kant, I. (1790). The Critique of Judgment. Amherst, NY: Prometheus Books.

Keltner, D. and Haidt, J. (2003). "Approaching awe, a moral, spiritual, and aesthetic". Cognition and Emotion, 17(2): 297-314.

Konecni, V. J., Wanic, R. A., and Brown, A. (2007). "Emotional and aesthetic antecedents and consequences of music-induced thrills". Am J Psychol, 120(4): 619-43.

Lazarus, R. S. (1991). Emotion and Adaptation. New York: Oxford University Press.

Lévi-Strauss, C. (1963). Structural Anthropology. Basic Books.

Lorenz, K. (1970). Trois essais sur le comportement animal et humain, Paris : Seuil.

Lovejoy, A. O. (1940). "Reflections on the history of ideas". Journal of the History of Ideas, 1(1): 3-23.

Lupasco, S. Logique et contradiction. (1947). Paris : P.U.F.

Mach, E. (1959). The Analysis of Sensations, and the Relation of the Physical to the Psycbical. New York: Dover Publications.

Mach, E. (1976). Knowledge and Error: Sketches on the Psychology of Enquiry. v. 3. Dordrecht: D. Reidel Pub. Co.

Maruskin, L. A., Thrash, T. M., and Elliot, A. J. (2012). "The chills as a psychological construct: content universe, factor structure, affective composition, elicitors, trait antecedents, and consequences". J Pers Soc Psychol, 103(1): 135-57.

McCrae, R. R. (2007). "Aesthetic chills as a universal marker of openness to experience". Motivation and Emotion, 31(1): 5-11.

Nabokov, V. V. and Bowers, F. (1981). Lectures on literature. New York: Harcourt Brace Jovanovich.

Neff, D. L. (1987). “Aesthetics and power", in Pāmbin Tuḷal. Ethnology, 26(1) : 63-71.

O'Connor, J., Robertson, E. (2015). “The works of Charles Hermite”, MacTutor History of Mathematics archive, November.

Panksepp, J. (1995). The emotional sources of "chills" induced by music. Music Perception, 13: 171-207.

Panksepp, J. and Bernatzky, G. (2002). "Emotional sounds and the brain: the neuro-affective foundations of musical appreciation". Behav Processes, 60(2):133-155. 
HSS, vol. IV, no. 3 (2015): 26-41

Pearsall, P. (2007). "Awe: the delights and dangers of our eleventh emotion". Health Communications, Deerfield Beach, Fla.

Perlovsky, L. (2006a). "Modeling field theory of higher cognitive functions". In Loula, A., Gudwin, R., and Queiroz, J., editors, Artificial Cognition Systems, chapter 64-105. Hershey, PA: Idea Group.

Perlovsky, L. (2006b). "Toward physics of the mind: Concepts, emotions, consciousness, and symbols". Phys. Life Rev., 3(1):22-55.

Perlovsky, L., R.W., D., and Ilin, R. (2011). "Emotional cognitive neural algorithms with engineering applications". In Dynamic Logic: from vague to crisp. Heidelberg: Springer.

Schlick, M. (1979). "A new philosophy of experience" (1932). In Philosophical Papers (1925- 1936), chapter 225-237. Dordrecht: D. Reidel Pub. Co.

Schlick, M., Mulder, H. L., and Velde-Schlick, B. F. B. v. d. (1979). Philosophical Papers. volume v. 11. Dordrecht : D. Reidel Pub. Co.

Schoeller, F. (2015) "Knowledge, curiosity, and aesthetic chills". Front. Psychol. 6:1546. Doi: 10.3389/fpsyg.2015.01546

Schoeller, F. (2014). La mécanique cognitive des films narratifs. Paris : École des Hautes Études en Sciences Sociales.

Simon, H. A. (1962). "The architecture of complexity". Proceedings of the American Philoso-phical Society, 106(6): 467-482.

Simon, H. A. (1967). "Motivational and emotional controls of cognition". Psychol Rev, 74(1): 29-39.

Sloboda, J. A. (1991). "Music structure and emotional response: some empirical findings". Psychology of Music, 19: 110-120.

Srejovic, D. (1972). "La religion de la culture de Lepenski Vir". Les religions de la prébistoire, Valcamonica, 18-23, Centro Camuno di Studi Preistorici.

Waismann, F. (1979). "Introduction". In Moritz Schlick Philosophical Papers, volume II. Springer, Netherlands.

1 We use knowledge in the most general sense; i.e., information about the world stored in memory, ranging from the everyday to the formal, that is likely to be true, that the subject has justification for believing and that is coherent (see e.g., Carruthers, 1992 ; Lehrer, 1990).

2 Cronin's work on the K-meson system lead him and his colleague to the discovery of the phenomenon of charge parity violation, discovery for which they earned a Nobel prize in physics (1981).

3 'Le jeune homme s'avance d'un pas incertain, sa main téméraire va toucher le voile sacré ; mais un frisson subit agite tous ses membres et un bras invisible le 


\section{HSS, vol. IV, no. 3 (2015): 26-41}

repousse au loin. - Malheureux ! lui crie une voix intérieure, que vas-tu faire ? Veux-tu porter atteinte à la Divinité ? Nul homme, a dit l'oracle, ne soulèvera ce voile, si je ne le seconde moi-même. Mais ce même oracle n'a-t-il pas ajouté : Celui qui arrachera ce voile verra la vérité? - Qu'importe ce qu'il y a là derrière ? s'écrie le jeune homme, je veux le soulever, je veux la voir. - La voir ! répète l'écho railleur". Schiller, F. L'image voilée de Sä̈s Traduction de Xavier Marmier, Les Cahiers d'Orient et d'Occident, Supplément à la Lettre Novalis, $n^{\circ} 44$.

4 "Et une fois encore je lançai un regard en arrière dans la froide nuit des hommes et je frissonnai et je pleurai de joie tant j'étais heureux, et je prononçai, me semble-t-il, ces paroles, mais qui étaient plutôt comme le froissement du feu qui s'élève et se dégage de la cendre... O Toi, pensais-je, toi et tes dieux Nature ! Il a fini de me hanter, ce songe des choses humaines, et je le dis, toi seule es vivante, et tout ce que l'inquiétude des hommes a obtenu par violence ou industrie fond, comme perles de cire, rejeté par tes flammes ! Combien de temps y a-t-il qu'ils vivent privés de toi ? et combien que leur foule t'insulte et profane ton nom avec celui de tes dieux, les dieux sereins et bienheureux de la vie !” [...] Traduction Robert Rovini (1968 : 198).

\section{Biographical note}

Félix Schoeller graduated from the École des Hautes Études en Sciences Sociales (EHESS) where he studied cellular neurobiology, psychophysics and philosophy of mind. He is currently writing a doctoral thesis (CRAL) encompassing the fields of philosophy, psychology, biology and mathematics while perfecting his studies at the University of Copenhagen. His actual research concerns the problem of natural curiosity, the principle of economy of thought and the relation between beauty, simplicity and truth. 